\title{
The standard of living in Serbia during the transition
}

\begin{abstract}
This article addresses changes in the standard of living in Serbia since the reform period got underway in 2000. In doing so, the author also addresses poverty, since the two issues are closely bound together. Locating his perspective clearly in the international context of a contemporary world of growing inequality, the author notes that standard of living is a key factor in the success of a political system. Dividing Serbia's post-2000 period into three, the article identifies the successes of the early part of the period which was, however, brought to a juddering halt by the international financial and economic crisis in 2008. Indeed, much of the progress in the early part of the last decade seems to have been reversed, with the standard of living falling again and poverty rising. Tackling this is a complex issue, not least given that necessary reforms in the education system pose tough questions in the context of a 'brain drain', while improvements in health, equally necessary as part of the same strategy, have a long way to go to overcome existing perspectives and problems.
\end{abstract}

Keywords: standard of living, transition, crisis, poverty, reforms, health care, education, social justice

\section{Introductory notes}

If we look back at human history through time, then we would, relatively easily, notice some of its constants - the social phenomena that have appeared in all periods of time, in all forms of social order and in all individual societies. Unfortunately, poverty is one of these social phenomena. It may naturally have occurred at different levels and to different extent, but there is no society whatsoever that has not faced the problem of poverty. It is also obvious that, despite indisputable economic and technological development, representing the ability of people to produce growing amounts of material and spiritual goods, poverty is part of the contemporary reality or, more precisely, the contemporary world is divided into a minority of rich people and a growing majority of poor ones.

Of course, we must also take into account objective changes in the criteria for defining poverty, as these are substantially different than they were several decades ago. We should acknowledge this as a warning and realise that poverty is a changing, developing and dynamic category. Basically, through different manifestations throughout history, two basic causes have emerged - insufficient creative force, that is, the capacities of human work and the human mind to create the necessary amount of material goods; and injustice in dividing material and spiritual goods, in which case privileged social groups have appropriated a larger part of social wealth, leaving the majority with a share that is often insufficient even for their basic biological survival. 
However, there is something that is also of great significance in the contemporary age - precisely because of the development of science and new technologies, and education becoming available to members of the broadest social classes, substantial changes have been made in the economic, social, sociological, legal and ethical approaches to poverty. The core of those changes can be seen in the attitude that poverty is not a matter of evil fate that has accidentally hit certain nations, social classes, individuals or parts of the world. On the contrary, contemporary social thought today sees poverty, at the beginning of the $21^{\text {st }}$ century, as a matter of choice, given certain development strategies and the ability of ruling people to define and realise this strategy in a clear and recognisable way.

It is from that point of view that we should start defining and analysing the phenomenon of poverty in societies in transition. The starting point in this respect is the theoretical and practical defining of the standard of living as a broader economic, social and moral category. The fact is that the standard of living is actually a multi-disciplinary, complex and, most importantly, civilisational category that encompasses culture; tradition; way of life; basic individual and social values; the order of these values; the level and character of education; etc.

Of course, even in societies in transition, as well as in more developed societies, the standard of living is the key factor in the success of a political system, or of the politicians who run it, meaning that poverty in its broader scales represents an indicator of political failure and, of course, a source of social conflict.

\section{Elements for defining the standard of living - the Serbian case}

The term 'standard of living' is well-known in the economic literature. When defining it, we can take into consideration both its broad and its narrow meaning. In the broadest sense, the standard of living signifies the full range of living and working conditions. It has three components:

1. living conditions

2. working conditions

3. social conditions - i.e. individual and collective spending.

After the 1990s, when the entire economy of Serbia regressed, as did the standard of living of its citizens, the period reforms got underway and, after 2000, the conditions for the start of the transition were created. In this article we monitor changes in the standard of living of Serbian citizens, starting from 2000 until today. We monitor the structure of citizens' individual expenditure, collective expenditure and poverty trends in Serbia on the basis of three general periods:

- the period from 2000-2007

- the period from 2008-2009

- the period from 2009-2012

\section{From 2000 to 2007}

During the transition in Serbia, from 2001 to 2007, there was a certain improvement in citizens' standard of living. Actual earnings grew at an average annual rate of $15.1 \%$, rising from $€ 102$ in 2001 to $€ 347$ in 2007 . This had a positive effect on 
citizens' spending patterns. We can analyse the structure of citizens' personal spending during this period; the following table explores the data on personal spending for the period 2003-2005:

Table 1 - Structure of personal expenditure of Serbian citizens, 2003-2005

\begin{tabular}{|l|r|r|c|}
\hline & $\mathbf{2 0 0 3}$ & $\mathbf{2 0 0 4}$ & $\mathbf{2 0 0 5}$ \\
\hline Food and non-alcoholic beverages & 42.5 & 39.9 & 37.1 \\
\hline Alcoholic beverages and cigarettes & 5.2 & 5.1 & 4.6 \\
\hline Rent, water, electricity, gas & 15.1 & 16.4 & 17.5 \\
\hline Health care & 3.2 & 3.5 & 4.2 \\
\hline Education & 1.6 & 1.7 & 2.0 \\
\hline Restaurants and hotels & 1.2 & 1.3 & 1.5 \\
\hline Other goods & 5.3 & 5.8 & 5.0 \\
\hline
\end{tabular}

The table shows that the share of spending on food and non-alcoholic beverages gradually decreased, from $42.5 \%$ in 2003 to $37.1 \%$ in 2005 . A decrease in the share taken by such survival goods shows an increase in people's standard of living. In the same period, we can see that expenditure on restaurants and hotels, considered as luxury goods, gradually increased from $1.2 \%$ in 2003 to $1.5 \%$ in 2005 .

The increase in the standard of living in these years can also be proven by other factors. In the Serbian Human Development Report from 2008 we can establish some data on height of HDI indicators for Serbia. In 2005, the human development index was 0.804 , ranking Serbia among those countries with the highest HDI values.

Finally for this period as regards personal expenditure, we can see that the value of the Gini coefficient, indicating inequality in the division of income, has been decreasing:

Table 2 - Gini coefficient dynamics in Serbia, 2003-2006

\begin{tabular}{|l|l|}
\hline 2003 & 0.28 \\
\hline 2004 & 0.31 \\
\hline 2005 & 0.29 \\
\hline 2006 & 0.25 \\
\hline
\end{tabular}

As for collective spending, we can highlight the segments of education and health. One of the most important tasks after 2000 was the reform of the education system at all levels and harmonising this with European practice. In 2001, Serbia obtained observer status in the Bologna process and in 2003, after accepting the Report on the state of high education and education development strategy, it obtained full membership. In 2003, the Law on the foundation of education and upbringing was passed. 
According to the 2002 Census, $3.45 \%$ of the population was illiterate, $17 \%$ had finished primary schooling, $41 \%$ high school and $10 \%$ faculties or vocational studies. Research from 2005, after the commencement of the application of the Bologna process, showed that Serbia was in $41^{\text {st }}$ place of 43 . By 2007, however, Serbia had reached the top ten, with an average mark of implementation efficiency of 4 (out of a maximum 5). Work done in the field of education also needs to highlight that Serbia had responded to the multicultural needs of Serbian citizens, and classes in primary and high schools could be carried out even in minority languages.

The basic cause of the decreasing number of students in Serbia is the constant decrease in the birth rate in Serbia. What is also worrying is that the level of education of vulnerable groups (people with disabilities, displaced people, Roma, etc.) is far below the national average. The primary cause is poverty, but also the absence of personal documents, as is the case with Roma.

Concerning the health care system, its main characteristics in Serbia at the beginning of the transition period were deserted capital infrastructure facilities and old equipment. According to data from the Serbian Human Development Report from 2008, over $72 \%$ of equipment was more than ten years old. The amounts given over per capita to health care in Serbia in 2000 were \$ 62, while in 2001 they had somewhat increased to $\$ 82$.

The Serbian health care system during this period was, however, financially insolvent with enormous debts being owed to the Republic Health Insurance Fund. The consequences of these debts were monies being owed to suppliers of medicines, which resulted in a lack of medicines being provided. Attempts had been made to address the situation by way of keeping health services at extremely low prices, resulting in low salaries in the health system, demoralisation and a lack of motivation among health workers, as well as informal payments, corruption and dissatisfaction with the services provided.

However, certain improvements did take place. Health system reform in Serbia was supported by the system of health care and public health. In the period from 2005 to 2007 , Serbia increased the amounts given over to public health care from $5.5 \%$ to $6 \%$ of gross national product.

Serbia managed to reach its goal and lower the mortality rate among children less than five years of age, although these indicators are still below European ones. Also, it has been confirmed that coverage of basic vaccines for children in 2005 had reached $99 \%$.

According to basic poverty indicators, poverty significantly decreased in this period. Based on the data from the table below, we may conclude that the transition had positively affected the standard of living of the lowest social classes. 
Table 3 - Poverty indicators in Serbia, 2006-2008

\begin{tabular}{|l|c|c|c|}
\hline & $\mathbf{2 0 0 6}$ & $\mathbf{2 0 0 7}$ & $\mathbf{2 0 0 8}$ (Q1-Q3) \\
\hline Absolute poverty line (dinars) & 6221 & 6225 & 7323 \\
\hline Percentage of people in poverty & 8.8 & 8.3 & 6.1 \\
\hline Poverty depth & 2.1 & 1.9 & 1.2 \\
\hline Poverty severity & 0.8 & 0.7 & 0.4 \\
\hline
\end{tabular}

From 2008 to 2009

A sudden deterioration in the business climate occurred in September 2008 with the collapse of major financial corporations in the USA. The flow of this economic crisis reached Serbia at the same time as it did other countries of the world. Economic growth, which had been substantial in the middle of the decade, was shaken. From GNP growing by $6.9 \%$ in 2007 , this fell back to $5.5 \%$ in 2008 . The financial and economic crises have influenced a decrease in the income of Serbian people through several channels:

- decrease in employment; and an increase in unemployment

- a pensions freeze

- increases in outstanding loans due to a depreciation of the dinar

- reduced lending by banks.

According to data from the Household Budget Survey, employment in Serbia in 2009 decreased by $5.8 \%$, meaning that unemployment strongly increased, reached a total of 488600 people, while the rate of unemployment increased from $14 \%$ in 2008 to $15.6 \%$ in 2009 . Consequently, poverty significantly increased in this period: by the end of 2008, the poverty rate had already climbed to $7.4 \%$, i.e. 550000 people.

What is the right strategy for surviving such a crisis? Most people seek to reduce their expenditure or postpone it. Households usually postpone expenditure on all items other than food. Amounts given over to food increased from $37.1 \%$ in 2005 to $41.3 \%$ in 2008, according to the 2008 Household Budget Survey, while shopping for clothes, furniture, domestic equipment and other permanent consumer goods fell drastically. Many people used their savings as a survival strategy, postponed health insurance payments, borrowed money from friends or relatives and postponed credit card repayments.

In the following table, we can see the trends in the amounts given for separate items of individual spending: 
Table 4 - Structure of personal expenditure of Serbian citizens, 2006-2009

\begin{tabular}{|l|r|r|r|c|}
\hline & $\mathbf{2 0 0 6}$ & $\mathbf{2 0 0 7}$ & $\mathbf{2 0 0 8}$ & $\mathbf{2 0 0 9}$ \\
\hline Food and non-alcoholic beverages & 39.0 & 40.3 & 41.3 & 41.2 \\
\hline Alcoholic beverages and cigarettes & 4.4 & 4.8 & 4.5 & 4.5 \\
\hline Rent, water, electricity, gas & 16.1 & 10.3 & 9.4 & 9.0 \\
\hline Health care & 4.1 & 4.2 & 4.0 & 3.7 \\
\hline Education & 1.1 & 1.1 & 1.0 & 1.0 \\
\hline Restaurants and hotels & 1.4 & 1.8 & 2.0 & 2.0 \\
\hline Other goods & 4.0 & 4.2 & 4.1 & 4.4 \\
\hline
\end{tabular}

We can see that, from 2006 to 2009, when the crisis reached its climax, amounts given over to food and non-alcoholic beverages increased, implying a drop in people's standard of living.

In percentage terms, this share increased from $39 \%$ to $41.2 \%$ in 2009 , but Serbia is still suffering and the trends are ongoing.

\section{From 2009 to 2012}

In 2010, the amounts given over to food and non-alcoholic beverages again increased, to $41.3 \%$. The Human Development Index (from that same year) was 0.735 . The methodology as regards the calculation of the Index had changed in the meantime, but it shows that the standard of living was significantly lower than in 2005. And, according to this indicator, our country no longer occupies such a high place in European comparison, which can be seen in Figure 1: 
Figure 1 - Human development index of a selection of European countries, 2006-2009

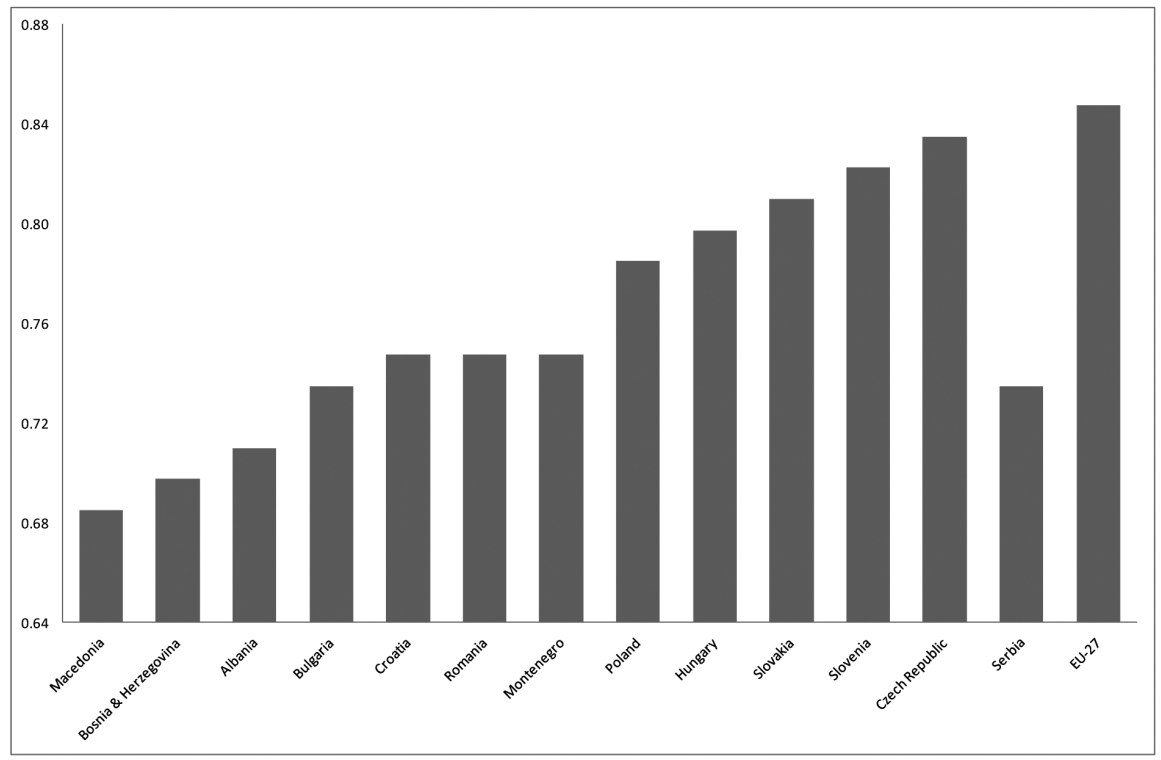

Compared to the surrounding countries, we have a higher HDI than only Macedonia, Bosnia \& Herzegovina and Albania. According to Eurostat data, per capita spending in Serbia is around 2.5 times lower than in the rest of Europe, implying a figure of $44 \%$ of the EU average. The population is bombarded from every conceivable direction with news that the standard of living is going up, but the facts do not prove it. In the second quarter of 2012, the amount given over to food and non-alcoholic beverages grew even higher (to $43.7 \%$ of total personal expenditure). If we compare such data with those of developed countries, where they stand at $15-20 \%$, we can see that our country is way behind.

As for supplies of permanent consumer goods, there is a small percentage of people who do not have a TV, a boiler or a washing machine. At the same time, there is a lower supply of cars: in 2006, the share of car ownership was $47 \%$ of households but, in 2012, this had dropped to $43 \%$.

Furthermore, according to an analysis by the International Monetary Fund (from April 2012), Serbia is in $75^{\text {th }}$ place in the world regarding its standard of living, based on a gross national product per capita that stood at 6081 Serbian dinars. How does Serbia plan to get itself out of such a bad place?

Firstly, we may examine the development of education in Serbia. Today, $4.5 \%$ of the national budget goes on education. According to the Strategy for Education Development in Serbia, however, this figure should reach $6 \%$ by 2020 . 
This Strategy states that:

- a minimum $98 \%$ of children should attend primary school, with a minimum $93 \%$ finishing it

- $88 \%$ of children should go on to high school, while there should be at least $40 \%$ of young adults thereafter enrolling in a faculty or other higher educational institution

- $7 \%$ of adults should partake in some form of adult education.

The function of primary education is to give students basic education in all fields significant for life in a modern world and to develop the functional knowledge, attitudes and values necessary for forming national and cultural identity. The key problems that confront primary education in Serbia are a low quality of knowledge and skills gained by primary school students and the significant percentage who do not finish their primary schooling. According to data from 2010 of the Statistical Office of the Republic of Serbia, $94.5 \%$ of children went to primary school while $5 \%$ do not go to school at all; and around $22 \%$ (according to the Census from 2002) do not finish primary school.

As for high school education, there is a trend of a growing number of students going on to high school, from $76.4 \%$ in 2005 to $85 \%$ in 2011 . If we pay attention to the fields of high vocational education, students have most interest in economy, law and administration (13.5\%); engineering (10.5\%); and medicine ( $8 \%$ ).

Through organised studies and research, the mission of high school education is constantly to transfer and create scientific knowledge and professional competence, making room for social, cultural, economic and other form of progress of our country and its citizens. According to the Education Development Strategy in Serbia, the greatest flaws of our high school education are:

- a teaching staff that sticks to traditions and which is not ready for change

- accepting a large number of students, for financial reasons, leading to a lower quality of studies.

The reforms which have been started in the education system need to be applied with the full participation of both students and teachers, as well as high school educational institutions, employers, public and the state. According to this strategy, the plan is to have around $40 \%$ young people leaving education as graduates by 2020 , which is much higher than the current figure of $11 \%$.

The great problem our country continues to face is the so-called 'brain drain'; in 2011 , the only country which was 'worse' in this regard than us was Guinea-Bissau. According to some surveys, $30 \%$ of students would leave the country after finishing their studies, and there is also a great number of people who prefer to finish their studies abroad.

Unless the efficiency of our labour market is improved, what will happen is that we will educate our population to work abroad, which certainly does not contribute to the country's development.

Collecting statistical data in the field of the health care system is the goal of the Institute of Public Health of Serbia 'Dr Milan Jovanović Batut'. According to its reports, the health care system in Serbia is making slow progress, as shown by the increase in the number of doctors between 2007 and 2010. Annually, 5.7\% of gross domestic 
product (around $€ 250$ per citizen per year) is set aside from the budget of the Republic of Serbia. However, many people think that this is not true and that we have to include the money that people give from their own pocket, meaning that this number would reach $11 \%$ (€ 500 per citizen).

According to research conducted by a health consumer organisation, Serbia is at the bottom of the European ladder in terms of the mortality of babies younger than one year old. It received a negative mark from this organisation, meaning that, for every 1000 live-born babies, there are more than six deaths (actually, 6.7) although this number is decreasing year-on-year.

As for vaccines, basic ones are provided for around $97.5 \%$ of the population, which is a relatively stable percentage over the years.

Through the project 'Serbian health care development', the Serbian government is trying to help different hospitals by donating equipment to them. We believe that it is important to mention that there are also many projects within which people are gathering together to help endangered groups. A great example is the action of the B92 fund 'Battle for babies', helping this most endangered group to fight for their future. The basic goal of this organisation is to provide the necessary equipment for delivering life support equipment to newborn babies in all maternity hospitals in Serbia.

\section{Instead of a conclusion - Poverty in Serbia}

Within the subject of the 'standard of living in Serbia', it is very important to mention poverty as well, at least briefly.

There are some important differences between absolute and relative poverty. Absolute poverty is linked to some standard of minimum needs, while relative poverty is determined by comparing those of different groups of citizens. This article has sought, at least in part, to address how Serbia came to find itself in a state of poverty: up until the 1990s, Serbia was at a rather high level of development, judging by the amount of per capita gross domestic product. During the nineties, however, it fell into a state of crisis - the country fell apart, a large number of refugees from former Yugoslav republics fled back to Serbia and GDP dropped while the unemployment rate soared higher, the UN imposed sanctions upon the country, and the bombing in 1999 followed. All this led to a poverty rate of $10.6 \%$ in 2002 ; that is, over 800000 people found themselves below the poverty line of 4489 dinars. However, if we moved this line upwards a fraction to 5507 dinars, the number of poor people would be around 1.6 million, which represents a substantial increase. Clearly, it was necessary to carry out certain reforms.

In 2003, the Serbian government created its Strategy for Poverty Reduction in Serbia. This implied that the unemployment rate would drop by one-half by 2010 . However, even though the poverty rate dropped from 2001 to 2003 as a consequence of the reforms which had got underway rather well, this was still too short a timeframe in which to cover the great production losses from the previous period. Today, the poverty rate is still increasing; from $6.9 \%$ in 2009 , it rose to $9.2 \%$ in 2010 , i.e. 680000 in people. Those who are most endangered, and where policy needs to address itself the most, are old people and children who live in multi-member households. 


\section{References}

Devetaković, Stevan, Biljana Jovanović Gavrilović and Gojko Rikalović (2013) Nacionalna Ekonomija (National Economy) Ekonomski fakultet u Beogradu - Centar za izdavačku delatnost, Beograd.

Serbian Human Development Report 2008

Serbian Development Report 2010.

Survey on Household Budget in 2008/09/10/11.

Survey on Household Budget for the second quarter of 2012.

Matković, Gordana, Boško Mijatović and Marina Petković (2010) Impact of the Financial Crisis on the Labour Market and Living Conditions Outcomes Centre for Liberal-Democratic Studies.

Empirical food basket and standard indicators, 2001-2006.

Education Development Strategy in Serbia until 2002.

www.bitkazaporodilista.rs

Serbia Health Project.

Strategy For Poverty Reduction In Serbia, 2003.

Marinković, D (2012) Working World, Old Challenges In A New World VSSP: Belgrade. 